\title{
The Implementation of design thinking Models on the Entrepreneurship Learning in Vocational Schools
}

\author{
Laurensia Claudia Pratomo, Siswandari, Dewi Kusuma Wardani
}

Faculty of Teacher Training and Education of Sebelas Maret University, Indonesia

\begin{abstract}
This study aims to determine the implementation of the design thinking learning model in entrepreneurship education, especially in marketing media competencies. The experimental method was used in this study with 120 vocational school students in Surakarta as research objects. The data were obtained by distributing questionnaires to students. The data is processed using SPSS Statistics 23 application. The results of $\mathrm{N}$-Gain shows that students' creativity and entrepreneurial alertness in the experimental class has increased after receiving entrepreneurship education with Stanford D School's design thinking model. In the category of high creativity has increased by $7 \%$ while in the category of high entrepreneurial alertness has increased by $10 \%$.
\end{abstract}

Keywords-learning model, design thinking, entrepreneurship learning, vocational schools.

\section{INTRODUCTION}

Learners are increasingly required to have competence in order to answer challenges in the 21 st century, especially to prepare themselves in the workforce. The competencies needed include communication skills, collaboration, creativity, and critical Thinking [12]. The curriculum must be a platform to build knowledge and encourage learners so that they can develop new skills needed in the $21 \mathrm{st}$ Century [2]. In addition to the educational curriculum, there is also a new approach in learning that is effectively able to develop the students' ability to make decisions, analyse, and solve problems immediately [9]. In curriculum 2013 revised edition 2017 entrepreneurial learning especially in vocational schools is converted into creative and entrepreneurial product subjects with the hope that the students can become an entrepreneurial, able to utilize biological wealth, empower the environment, and provide innovation or breakthrough to solve problems and meet the needs of society. Although the curriculum has been designed in such a way as to follow the demands in the 21 st century, unfortunately there are still many lessons that still use conventional approaches which are considered ineffective in creating students' skills, especially in entrepreneurship subjects [3]. There are various reasons why educators are reluctant to apply the methods or approaches according to the curriculum 2013, such as educators are not ready to face changes in the educational world, so they prefer to use conventional learning and the limitations of facilities and infrastructure available at school.

Apart from a variety of causes and barriers to the implementation of the model and learning approaches according to the 21 st century, an educator still have to develop the skills of each learner. In fact, learning is not only transferring the knowledge that an educator has but also growing and honing the skills of students. There is an approach that is able to integrate the students' $4 \mathrm{C}$ in learning; communication collaboration, creativity, and the ability of critical thinking through design thinking. Design thinking is an approach that can be used appropriately and effectively when applied to entrepreneurship learning [1]. Design thinking consists of collaboration that aims to solve problems by identifying and processing information or problems that occur around us, experience and feedback, and students apply $21 \mathrm{st}$ century skills such as communication, creativity, and critical thinking to solve problems [9]. Simple problems even complex problems can be solved through design thinking.

\section{LITERATURE REVIEW}

\subsection{Design Thinking As a problem solving approach}

Design thinking is adopted from the way a designer or designers work, they deal with various complex problems 
over the years, and then design and develop complex professional practices in their fields [8]. Why is design thinking said to be human-centered? In design thinking there is a systematic collaboration process with humans as the center of users [9], design thinking is created through a planned process so that it can eventually produce a condition or condition that is expected by humans [7]. In addition, design thinking is able to provide support and strengthen human dignity by solving various problems in the social, economic, political and cultural fields [13], so that solutions to these problems emerge such as certain decisions or policies. Design thinking has a special feature because through the work process of a designer it helps us produce, teach, study, and apply human centered techniques systematically with the aim of solving problems creatively and innovatively in terms of business, state, and everyday life [6].

The world of education is inseparable from design thinking that is also capable of creating a learning experience that is centered on the learner or student centered [14]. The basic thing needed in design thinking is to build the ideas of each individual, because design thinking involves processes and thoughts in it [9]. There are several characteristics of a designer or a design thinker [10] some of them: human and environment centered concern, ability to visualize, predisposition toward multifunctionality, systemic vision, the ability to use language as a tool, affinity for teamwork, avoiding the necessity of choice.

Based on this description, an individual known as a design thinker is able to communicate, collaborate, and collaborate with others. Besides that, the design thinker must think critically and creatively to solve problems and find solutions. The application of the design thinking approach in education is expected to be able to improve and train the skills of students as a design thinker should have in solving problems in society.

\subsection{Process or Stage of Design Thinking}

Due to the demands of the changing times in the era of distribution, humans must be able to overcome every problem they face. The desire to develop and become a better human factor always explores the possibilities that can be a solution to their problems. Design Thinking enables us to understand problems by approaching challenges and looking for the most appropriate steps or ways to overcome them according to human needs [5]. Then how is the design thinking process? There are five stages in design Thinking [4], namely:

(1) Empathize. At the first stage we are invited to understand the problems that want to be solved emphatically. One needs to go directly into the environment where the problem occurs in order to be able to understand the experience and increase the empathy of the researcher. Through this empathy process allows researchers to prioritize the needs of users (who are involved in problems). The empathy stage also provides information that can be used at a later stage, in addition to developing an understanding of users, user needs, and problems that are the basis for product or solution development.

(2) Define. After going through the second stage, next is the define stage. The information obtained in the Empathy stage is collected at this stage and then analyzes and synthesizes the problem. Then comes the core problem we identified earlier. It should be remembered that the problem must be based or human-centered manner and not self-interest or other parties. The define stage helps the designer or researcher gather ideas that are useful in solving problems.

(3) Ideate. At this stage, a designer is ready to come up with an idea. After going through the empathy stage we are able to understand user needs (human need), then at the define stage we must analyze and synthesize the observations that produce basic human-centered problems. Furthermore, at this ideate stage, we are challenged to think of new solutions by "thinking outside the box" so as to be able to overcome the problem. It is very important if we are able to get various kinds of ideas or solutions to this problem, then we must select some of these ideation techniques to find the best way to solve or avoid the problem.

(4) Prototype. At this stage an output or output can be formed with a minimalist design or a prototype (for example, a cheaper and reduced version of the product) so that it can be seen whether the solution can solve the problem. Prototypes can be tested on groups or research teams or certain groups other than the development team. This stage is called the experimental stage because the team needs to test the design and evaluate the user experience. In the end the design team came up with a better idea because of the obstacles that occurred during the design trial process.

(5) Test. The prototype or design that has been obtained from the previous stage is tested by the evaluator and the results of the evaluation carried out are a repetitive process. The results obtained during the test can be used to explain the problem again, informing them of; user understanding; conditions of use; and user response. This stage allows changes and improvements to the prototype to gain an understanding of the product and its users. 


\subsection{Implementation of Design Thinking in Entrepreneurial Learning}

Design thinking has been applied in various fields including education. There are several examples of educational institutions and communities that use design thinking as a guideline for activities including Design Thinking for Educators, Ideate High Academy, Interaction Design Foundation, Darden Executive Education, The Nothos Lab. Unfortunately in Indonesia itself is still quite unfamiliar with the use of design thinking in learning, in this case especially in entrepreneurship learning. Design thinking can be applied as a learning approach. The appropriate learning method to combine with design thinking is project based learning and problem based learning depending on the learning objectives to be achieved [11].

Design thinking contains two phases, namely analytical and synthetic. In the analytic phase, it consists of (1) discovery; at this stage the existing theory will be studied, (2) understanding, observing, and evaluating; at this analytical stage it allows observation activities to solve problems so that they can find solutions. In the synthetic phase there is a process of creating ideas so that the application of theory needs to be used. This synthetic stage is in accordance with the design thinking stage, namely ideation, prototyping, and testing which focuses on the creation process. The two analytical and synthetic stages must be interconnected so that they are able to create problem solutions through the observation process at the analytic stage and end with testing ideas or solutions that can be used. However, this process can occur repeatedly at every stage [9]. Because entrepreneurship learning is applied in secondary education, the design thinking approach is designed to be simpler than in higher education.

\subsection{Research Objective}

The purpose of this study was to determine the application of a problem-solving approach as well as a project-based approach, namely design thinking with the Stanford model on students' creativity and entrepreneurial alertness. The matter of problem in this research is (1) Does design thinking can enhance the creativity of students through entrepreneurial learning? (2) Does design thinking can enhance students' entrepreneurial alertness through entrepreneurial learning?

\section{RESEARCH OBJECTIVE}

The study used quasi-experiment methods by distributing questionnaires to students in the experimental class and control class, each class consists of 60 students. The research questionnaire uses a Likert scale with 4 scales i.e. from strongly agreed to highly disagreeing and data tested using SPSS 23 programs. Results of pretest and posttest are gathered and used to determine the application of design thinking models to increased ability and entrepreneurial alertness of students. The tabulation of the research data is further analyzed into the category of creativity and entrepreneurial alertness of students. These categories can be viewed in table 1 . As for $\mathrm{X}$ is a questionnaires scores, $\sigma$ is Standard Deviation, and $\mu$ is average score.

Table 1. Category of Creativity and Entrepreneurial Alertness (N-Gain)

\begin{tabular}{cc}
\hline Interval & Description \\
\hline $\mathrm{X}<\mu-0,5 \sigma$ & Low \\
$\mu-0,5 \sigma \leq X \leq \mu+0,5 \sigma$ & Moderate \\
$X>\mu+0,5 \sigma$ & High \\
\hline
\end{tabular}

\section{RESULT AND DISCUSSION}

Apart from going through the validity test, reliability test, and classical assumption test, the collected data were then processed using the SPSS Statistics 23 program to produce data as in table 2 .

Table 2. Results of Data Processing Using SPSS

\begin{tabular}{lcccc}
\hline & \multicolumn{2}{c}{ Creativity } & \multicolumn{2}{c}{$\begin{array}{c}\text { Entrepreneurial } \\
\text { Alertness }\end{array}$} \\
\cline { 2 - 5 } & Mean & Std. Dev & Mean & Std. Dev \\
\hline Pretest Ex & 33,63 & 4,202 & 51,48 & 7,031 \\
Posttest Ex & 36,43 & 4,500 & 60,03 & 6,454 \\
Pretest Con & 30,63 & 3,813 & 49,48 & 8,050 \\
Posttest Con & 30,47 & 3,657 & 51,98 & 6,573 \\
\hline
\end{tabular}

Table 2 is the result of data processing variables of creativity and entrepreneurial alertness using SPSS. Creativity in the Pretests class experiments has mean 33.63 and Std. Dev 4.202, while creativity in the Posttest class of experimentation has mean 36.43 and STD. Dev 4.500. Entrepreneurial alertness on the experimental class pretests has mean 51.48 and Std. Dev 7.031, while entrepreneurial alertness on the experimental class posttest has mean 60.03 and STD. Dev 6.454. The creativity on the control class pretests has the mean 30.63 and STD. Dev 3.813, while the creativity on the Posttest control class has mean 30.47 and STD. Dev 3.657. Entrepreneurial alertness on the control class pretests has mean 49.48 and Std. Dev 8.050, while 
entrepreneurial alertness in posttest-class control has mean 51.98 and STD. Dev 6.573.

Table 3. Categories of Creativity

\begin{tabular}{llcc}
\hline Description & & Control Class & $\begin{array}{c}\text { Experimental } \\
\text { Class }\end{array}$ \\
\hline Low & Pretest & $\mathrm{X}<29$ & $\mathrm{X}<31$ \\
& Posttest & $\mathrm{X}<29$ & $\mathrm{X}<34$ \\
\hline Moderate & Pretest & $29 \leq \mathrm{X} \leq 32$ & $31 \leq \mathrm{X} \leq 36$ \\
& Posttest & $29 \leq \mathrm{X} \leq 32$ & $34 \leq \mathrm{X} \leq 39$ \\
\hline High & Pretest & $\mathrm{X}>32$ & $\mathrm{X}>36$ \\
& Posttest & $\mathrm{X}>32$ & $\mathrm{X}>39$ \\
\hline
\end{tabular}

After obtaining the results of data processing using SPSS then tabulations are made to determine the categories of students' creativity and entrepreneurial alertness before and after receiving treatment. The results of the tabulation of the prestest and posttest creativity questionnaires are shown in table 3. Before receiving treatment (pretest) students in the control class with high creativity were participants with a score above 32 , students in the control class with moderate creativity skills had scores between 29 and 32. While students in the control class with low creativity skills had a score below 29. It was also known that students in the experimental class with high creativity skills were participants with a score above 36 , students in the experimental class with moderate creativity skills had scores between 31 up to 36 , while students in the experimental class with low creativity skills had scores below 31 .

After receiving treatment (posttest) students in the control class with high creativity were participants with scores above 32 , students in the control class with moderate creativity had scores between 29 to 32, while students in the control class with low creativity had scores in below 29. It was also known that students in the experimental class with high creativity were participants with a score above 39 , students in the experimental class with moderate creativity had scores between 34 to 39 , while students in the experimental class with low creativity had scores below 34.

Table 4. Distribution of the Number of Students in Each Creativity Category

\begin{tabular}{llccc}
\hline Class & & High & Moderate & Low \\
\hline Control & Pretest & 19 & 21 & 20 \\
& Posttest & 19 & 22 & 19 \\
\hline Experimental & Pretest & 14 & 31 & 15
\end{tabular}

Posttest

18

27

15

Based on table 4, it is known that before receiving treatment (pretest), students in the control class with high creativity amounted to 19 students $(31 \%)$, students with moderate creativity amounted to 21 students (35\%), and students with low creativity were 20 students (33\%). Whereas in the experimental class, there were 14 students with high creativity (23\%), 31 students with moderate creativity (52\%), while those with low creativity were 15 (25\%). After receiving treatment (posttest) students in the control class with high creativity amounted to 19 students (32\%), students with moderate creativity numbered 22 (37\%), and students with low creativity were 19 (32\%). Whereas in the experimental class, there were 18 students with high creativity (30\%), 27 students with moderate creativity $(45 \%)$, while those with low creativity were 15 $(25 \%)$

In the control class there was no change in student creativity in the high category, which was still 19 students, in the moderate category there was an increase of 1 student from 21 students to 22 students, and there was a decrease in creativity in the low category as many as 1 person who originally numbered 20 students to become 19 students. Whereas in the experimental class, the low category had a fixed number of 15 students, while in the moderate category there was a decrease of 4 students, but in the high creativity category there was an increase of 4 students to 18 students. It can be concluded that there is an increase in creativity in the experimental class compared to the control class. The experimental class with the high creativity category increased by $7 \%$, from $23 \%$ to $30 \%$, while the control class with the high creativity category did not change.

Table 5. Categories of Entrepreneurial Alertness

\begin{tabular}{llcc}
\hline Description & & Control Class & $\begin{array}{c}\text { Experimental } \\
\text { Class }\end{array}$ \\
\hline Low & Pretest & $\mathrm{X}<45$ & $\mathrm{X}<48$ \\
& Posttest & $\mathrm{X}<49$ & $\mathrm{X}<57$ \\
\hline Moderate & Pretest & $45 \leq \mathrm{X} \leq 53$ & $48 \leq \mathrm{X} \leq 55$ \\
& Posttest & $49 \leq \mathrm{X} \leq 55$ & $57 \leq \mathrm{X} \leq 63$ \\
\hline High & Pretest & $\mathrm{X}>53$ & $\mathrm{X}>55$ \\
& Posttest & $\mathrm{X}>55$ & $\mathrm{X}>63$ \\
\hline
\end{tabular}

After obtaining the results of data processing using SPSS in table 2, tabulations are made to determine the categories of student entrepreneurial alertness before and after 
receiving treatment. The results of the tabulation of the prestest and posttest questionnaire on entrepreneurial alertness are shown in table 5.Before receiving treatment (pretest) students in the control class with high entrepreneurial alertness were participants with a score above 53, students in the control class with moderate entrepreneurial alertness had a score between 45 to 53, while students in the control class with low entrepreneurial alertness had scores below 45.It was also known that students in the experimental class with high entrepreneurial alertness were participants with scores above 55, students in the experimental class with moderate entrepreneurial alertness had scores in between 48 to 55 , while students in the experimental class with low entrepreneurial alertness had a score below 48 .

After receiving treatment (posttest), students in the control class with high entrepreneurial alertness were participants with scores above 55, students in the control class with moderate entrepreneurial alertness had scores between 49 to 55, while students in the control class with entrepreneurial alertness low has a score below 49. It is also known that students in the experimental class with high entrepreneurial alertness are participants with scores above 63 , students in the experimental class with moderate entrepreneurial alertness have a score between 57 to 63, while students in the experimental class with low entrepreneurial alertness has a score below 57.

Table 6. Distribution of the Number of Students in Each Entrepreneurial Alertness Category

\begin{tabular}{llccc}
\hline Class & & High & Moderate & Low \\
\hline Control & Pretest & 14 & 26 & 20 \\
& Posttest & 12 & 32 & 16 \\
\hline Experimental & Pretest & 13 & 33 & 14 \\
& Posttest & 19 & 27 & 14 \\
\hline
\end{tabular}

Based on table 6 , it is known that before receiving treatment (pretest), students in the control class with high entrepreneurial alertness were 14 students (23\%), students with moderate entrepreneurial alertness were 26 students (43\%), and students with low entrepreneurial alertness were 20 students $(33 \%)$. Whereas in the experimental class, there were 13 students with high entrepreneurial alertness $(22 \%), \quad 33$ students with moderate entrepreneurship alertness (55\%), while those with low entrepreneurial alertness were 14 students (23\%). After receiving treatment (posttest) students in the control class with high entrepreneurial alertness amounted to 12 students (20\%), 32 students with moderate entrepreneurial alertness $(53 \%)$, and 16 students with low entrepreneurial alertness ISSN: 2456-7620
(27\%). Meanwhile in the experimental class, there were 19 students with high entrepreneurial alertness (32\%), 27 students with moderate entrepreneurial alertness (45\%), while those with low entrepreneurial alertness were 14 students $(23 \%)$.

In the control class, although there was an increase in entrepreneurial alertness in the moderate category, from 26 students to 32 students and a decrease in entrepreneurial alertness in the low category, from 20 students to 16 students, it turns out that entrepreneurial alertness in the high category has decreased from 14 students to 12 students. Whereas in the experimental class there was no change in entrepreneurial alertness in the low category, which was still 14 students. In addition, there was an increase in entrepreneurial alertness in the high category from 13 students to 19 students. It can be concluded that there is an increase in entrepreneurial alertness in the experimental class compared to the control class. The experimental class with the high entrepreneurial alertness category increased by $10 \%$, from $22 \%$ to $32 \%$, while the control class with the high entrepreneurial alertness category decreased $3 \%$ from $23 \%$ to $20 \%$.

\section{CONCLUSION}

Based on the results of this study, it is known that there is an effect of the application of design thinking on the creativity and entrepreneurial alertness of vocational students. Design thinking is basically human centered because the problems experienced by everyone are expected to be solved by using the processes or stages contained in design thinking. The use of design thinking in entrepreneurship learning can improve communication skills, collaboration, creativity, and critical thinking in accordance with the demands of the 21 st century. In order to solve problems, students must communicate and collaborate with others (collaboration), besides that students think critically for can create ideas creatively so as to produce solutions that are applied or implemented to overcome the problem. This article is limited to the application of design thinking in vocational schools and it is hoped that in the future research on the application of design thinking in other studies with a wider scope will be carried out. Further researchers can design and develop problem-based learning and project-based learning methods that use a design thinking approach in entrepreneurship learning. 


\section{REFERENCES}

[1] Aflatoony, L., \& Wakkary, R. (2015). Thoughtful thinkers: secondary schoolers' learning about design thinking. Proceedings of 3rd International Conference for Design Education Researchers: LearnxDesign, 2, 563-574. Retrieved from http://summit.sfu.ca/item/15249

[2] Alismail, H. A., \& Mcguire, P. (2015). 21st century standards and curriculum: current research and practice. Journal of Education and Practice, 6(6), 150-155.

[3] Bauman, A., \& Lucy, C. (2019). The international journal of enhancing entrepreneurial education: developing competencies for. The International Journal of Management Education, 100293. https://doi.org/10.1016/j.ijme.2019.03.005

[4] Dam, R., \& Siang, T. (2019a). 5 Stages in the Design Thinking Process. Retrieved from Interaction Design Foundation website: https://www.interactiondesign.org/literature/article/5-stages-in-the-design-thinkingprocess

[5] Dam, R., \& Siang, T. (2019b). Design Thinking: New Innovative Thinking for New Problems. Retrieved from Interaction Design Foundation website: https://www.interaction-design.org/literature/article/designthinking-new-innovative-thinking-for-new-problems

[6] Dam, R., \& Siang, T. (2019c). What is Design Thinking and Why is it so Popular? Retrieved from Interaction Design Foundation website: https://www.interactiondesign.org/literature/article/what-is-design-thinking-andwhy-is-it-so-popular

[7] Dolak, F., Uebernickel, F., \& Brenner, W. (2013). Design Thinking and Design Science Research. Positioning Paper DESRIST 2013.

[8] Dorst, K. (2011). The core of 'design thinking' and its application. Design Studies, 32(6), 521-532. https://doi.org/10.1016/j.destud.2011.07.006

[9] Luka, I. (2014). Design Thinking In Pedagogy. Journal of Education Culture and Society, 5(2), 63-74. https://doi.org/10.15503/jecs20142.63.74

[10] Owen, C. (2007). Design thinking: notes on its nature and use. Design Research Quarterly, 2(1), 16-27.

[11] Ray, B. (2012). Design Thinking: Lessons for the Classroom. Retrieved from George Lucas Educational Foundation website: https://www.edutopia.org/blog/designthinking-betty-ray

[12] Rochmawati, A., \& Ridlo, S. (2019). Analysis Of $21 \mathrm{St}$ Century Skills Of Student On Implementation Project Based Learning And Problem Posing Models In Science Learning. Journal of Primary Education, 9(1), 58-67.

[13] Val, E., Gonzalez, I., Iriarte, I., Beitia, A., Lasa, G., \& Elkoro, M. (2017). Entrepreneurship education in European school curricula a design thinking approach to introduce entrepreneurship education in European school curricula. The Design Journal, 20:sup1, S754-S766.

[14] Welsh, M. A., \& Dehler, G. E. (2015). Combining critical reflection and design thinking to develop integrative learners. Journal of Management Education, 37(6), 771802. 